\title{
Comparative analytical study on effect of Bhavana on Karavellaka Churna (Momordica charantia Linn.) and Bhavita Karavellaka Churna
}

\author{
Research Article
}

\section{Manisha Choudhary ${ }^{1}$, Dhirajsingh S Rajput ${ }^{2 *}$}

\author{
1. Scholar, 2. Associate Professor, \\ Department of Rasashastra and Bhaishajya Kalpana, \\ Mahatma Gandhi Ayurved College Hospital \& Research Centre, Salod (H), Wardha (MH).
}

\begin{abstract}
Bhavana is an Ayurveda process of triturating a powdered drug with herbal juices or decoction. In classical texts this procedure is narrated to have potential to change or initiate positive therapeutic properties in a formulation. Ayurveda literature also shows that if Bhavana of drug juice is given to the powder of same drug then the final product will have few fold more activities than simple powder form of that drug. Present work was undertaken to study this concept on analytical ground as analysis provides basic understanding of changes in chemical composition which is actually related with therapeutic activities. Karavellaka (Momordica charantia Linn.) was chosen as drug for this work as it is well known drug for hyperglycemia. Powder of M. Charantia was made in 6 batches each of 1 $\mathrm{kg}$. Three batches were kept in powder form (Karavellaka Churna, KC) and remaining three batches were given Bhavana of M. Charantia juice (Bhavita Karavellaka Churna, BKC). Physico-chemical analysis along with nutrition value was done to access the proportion of change. All studied parameters showed higher range of values in BKC than KC. Similar result is observed in nutritional value analysis. All these results conclude that Bhavana has synergistic action in increasing concentration of chemical constitutes of the drug. The increase in concentration may reduce the therapeutic dose.
\end{abstract}

Key Words: Karavellaka, Momordica charantia Linn., Bhavana.

\section{Introduction}

Ayurveda specific processing method (Aushadhi Sanskara) of herbs as well as metals and minerals is one of the fundamental concept of Ayurveda pharmaceutics. Shodhana (purification), Jarana (open pan frying) and Marana (incineration to create metal/mineral calx) are most common processing's of single metallic and mineral drugs. On the other hand, Bhavana (trituration) and preparation of Ghana Satva (solidified extracts) are the two methods which can be utilized to enhance therapeutic efficacy of single herb. According to a research giving Bhavana to powder of a herb by using juice extracted from the same herb result in significant increase in therapeutic potential. The increased therapeutic potential can be accessed by various analytical testing's.(1,2)

\section{* Corresponding Author:}

Dhirajsingh S. Rajput,

Associate Professor, Department of Rasashastra and Bhaishajya Kalpana,

Mahatma Gandhi Ayurved College Hospital \& Research Centre,

Salod (H), Wardha (MH),

Email id: dhirajsingh.rajput@dmimsu.edu.in
In recent few years, the market of herbal medicine has grown significantly and there seems great competition to discover cost effective herbal medicine. Modification in dosage form or increasing the potency of available dosage form is also attracting focus of innovative researchers. Giving Bhavana to a drug by using juice extracted from the same drug (Bhavita herb) is one of the easiest, time saving and inexpensive procedure which has been studied on Rasayana Churna and Guduchi Churna and has been found positively enhancing the drug action.(3)

According to analytical point of view, Bhavana results in changing the chemical profile of Bhavita material. However such change need to be studied on analytical ground to know its actual extent as well as to know the change occurred in final product. Karavellaka (Momordica charantia Linn.) is one of the well known medicinal herbs which has Pramehaghna (anti-diabetic) activity and scientific researches has proven its antihyperglycaemic efficacy.(4,5) Considering the results of positive effect of Bhavana on Bhavita Dravya, an assumption can be made that Karavellaka Swarasa Bhavana may also result in changing physico-chemical nature of Bhavita Karavellaka Churna (BKC). Therefore present work is planned for comparative analytical evaluation of Karavellaka Churna (KC) and BKC. 
Material \& methods:

\section{Materials:}

M. charantia was used as a raw material. $9 \mathrm{~kg}$ $M$. charantia fruits were procured from local market of Wardha. $3 \mathrm{~kg} \mathrm{M}$. charantia for preparation of $\mathrm{KC}, 3 \mathrm{~kg}$ for extraction of juice for Bhavana and $3 \mathrm{~kg}$ for preparation of powder for BKC. Each $3 \mathrm{~kg}$ batch was again divided into batches of $1 \mathrm{~kg}$ for development of standard operating procedure (SOP). (Table 1)

\begin{tabular}{|c|l|l|l|}
\hline \multicolumn{3}{|l|}{ Table 1: Detail of ingredient and quantity } \\
\hline Sr. & $\begin{array}{l}\text { Batch and } \\
\text { Code }\end{array}$ & $\begin{array}{l}\text { Quantity of fresh } \\
\text { material }\end{array}$ & $\begin{array}{l}\text { Purpose } \\
\text { For Churna }\end{array}$ \\
\hline 1 & $\begin{array}{l}\text { Karavellaka } \\
\text { Churna }(\mathrm{KC})\end{array}$ & $\begin{array}{l}3 \mathrm{~kg}(1 \mathrm{~kg} \text { in each } \\
\text { sub batch) }\end{array}$ & $\begin{array}{l}\text { For } \text { pharation } \\
\text { (KC) }\end{array}$ \\
\hline 2 & $\begin{array}{l}\text { Bhavita } \\
\text { Karavellaka } \\
\text { Churna }(\mathrm{BKC})\end{array}$ & $\begin{array}{l}3 \mathrm{~kg}(1 \mathrm{~kg} \text { in each } \\
\text { sub batch) }\end{array}$ & $\begin{array}{l}\text { For } \\
\text { preparation of } \\
\text { 3times BKC }\end{array}$ \\
\hline 3 & $\begin{array}{l}\text { M. charantia } \\
\text { Fruits }\end{array}$ & $\begin{array}{l}\text { 3 kg (1 kg in each } \\
\text { sub batch) }\end{array}$ & $\begin{array}{l}\text { For extraction } \\
\text { of Swarasa } \\
\text { (juice) for } \\
\text { Bhavana }\end{array}$ \\
\hline
\end{tabular}

Methods

All collected $M$. charantia fruits were first washed and shade dried for 3 hours. Vertical section of $M$. charantia fruits was taken and seeds were removed from the interior part of fruit. (Fig.1 to 3) Then the seeds were made (excluding $3 \mathrm{~kg} \mathrm{M}$. charantia fruits required for Bhavana) into small pieces and fine paste was made by grinding in mixer. (Fig. 4 and 5) The paste was allowed to dry in hot air oven for 6 hrs per day at $60{ }^{\circ} \mathrm{C}$. It took 3 days for complete drying of the paste. The obtained dried powder for KC batches was sieved through mesh no. 80 and then stored in airtight plastic bottles. The dried powder of BKC batches was further subjected for 3 times Bhavana with M. charantia fruit juice. The juice was extracted by making paste of Karavellaka pieces and pressured filtering through cotton cloth. The obtained juice was utilized for 3 Bhavana to prepare BKC. (Fig. 6 to 8 )

\section{Analytical study}

Botanical identification of Karavellaka species was done from National Botanical centre, Bangalore. In analytical study, $\mathrm{KC}$ and $\mathrm{BKC}$ were tested by organoleptic and physico-chemical parameters. The organoleptic characters involved the testing of samples using sensory organs. These are four subjective parameters are colour, odour, taste and touch. Physicochemical parameters such as total ash, acid insoluble ash, alcohol-soluble extractive, water-soluble extractive, foreign matter and microbial contamination were analyzed as per pharmacopeia of India. Nutritional value of both the samples was also tested to understand the differences in their chemical components caused due to effect of Bhavana. The methods of analysis are as per given below.

\section{Determination of Protein(6)}

The pellet of sample tissue remaining after extraction of chlorophyll (ERT/REAC SOP \#2030, Chlorophyll Determination) is treated to remove lipids, then allowed to dissolve in $0.1 \mathrm{~N}$ Sodium Hydroxide $(\mathrm{NaOH})$ for 15 minutes to generate a crude protein extract. The solution is centrifuged, and duplicate 0.1 milliliters $(\mathrm{mL})$ aliquots are pipetted into separate test tubes. The protein content is determined on these duplicates using the Bicinchoninic Acid (BCA) method. This involves mixing the sample with reagents which react to form a product with a colour intensity that is proportional to the amount of protein in the sample. The colour is quantified as an absorbance reading in a spectrophotometer at a wavelength of 562 nanometers $(\mathrm{nm})$.

\section{Determination of Total Fat(7)}

$5.00 \mathrm{~g}$ sample was weighted on a torsion balance in a $50 \mathrm{ml}$ beaker. $0.5 \mathrm{ml}$ of 95 percent alcohol was added and sample was stirred until it is homogeneous. $0.5 \mathrm{ml}$ of 95 percent alcohol was added again and stirred thoroughly. Finally $1.0 \mathrm{ml}$ of 95 percent alcohol was added and stirred again. The contents of the beaker were washed into a Babcock 9 gm cream bottle, using a minimum quantity of ethyl alcohol, 50 per cent by volume. Centrifuged for 10 minutes at approximately 1200 r.p.m. More 50 percent of alcohol was added to bring the layer of fat just below the neck of the flask and again centrifuged for 5 minutes. Sufficient 50 percent alcohol was again added to bring the column of fat well within the neck of the flask and again centrifuged for 5 minutes. The flask was removed from the centrifuge and reading was noted for percentage of fat directly. The reading was multiplied by 1.8 to obtain the percentage of fat in the sample, since the bottle is calibrated for a $9 \mathrm{~g}$ sample.

\section{Determination of Carbohydrate( 8 )}

Total Carbohydrate content was determined by subtraction of the sum of the crude protein, total fat, moisture, and ash from the total weight of the sample.

\section{Determination of Total Mineral(9)}

Dried plant samples were ashed in a furnace by nitric (AR) and hydrochloric acid.(10) Afterwards, distilled water $(50 \mathrm{ml})$ was added to samples in a volumetric flask. Atomic Absorption Spectrometry was used for determination of mineral contents.

\section{Observation and Results}

On the basis of observations, it is clearly noted that average $92 \%$ weight loss occurs during making dry powder from wet $M$. charantia fruits including the loss 
due to removal of seeds. Average $1 \mathrm{~kg} \mathrm{M}$. charantia fruits has yield average 74.26 and $74.53 \mathrm{gm}$ dried powder in $\mathrm{KC}$ and BKC batches respectively. (Table 2) The $3 \mathrm{~kg} \mathrm{M}$. charantia fruits which were kept for extraction of juice yield average $336.33 \mathrm{ml}$ juice which was found sufficient for 3 times Bhavana to dried powder as the average weight of dried powder was 74.53 gm only. (Table 3) Bhavana was given for three consecutive days and the average duration for each day was 2.40 hours. Average $110 \mathrm{ml} M$. charantia juice was found sufficient for Bhavana to taken quantity of powder. (Table 4) Observations of organolepic characters of $\mathrm{KC}$ and $\mathrm{BKC}$ showed nearly same characteristics. The organoleptic parameters have very mild difference but it is not classifiable such as the colour of $\mathrm{BKC}$ is slightly more greenish brown than KC. [(Table 5) (Fig.9 and 10)] Analysis of KC and BKC revealed considerable difference in all parameters except in absence of foreign matter and microbial load. The observations indicate that every parameter have higher value in BKC compared to KC. (Table 6) Similar observations are detected in nutritional value analysis which also support the results obtained in physicochemical analysis. Highest difference is detected in Carbohydrate and Total energy. In both the parameters BKC showed much more proportion of carbohydrate and total energy compared to KC. (Table 7).

Table 2: Weight changes during preparation of $M$. charantia powder

\begin{tabular}{|c|c|c|c|c|c|c|c|c|c|}
\hline \multirow{2}{*}{ Batch } & \multirow{2}{*}{$\begin{array}{c}\text { Sub } \\
\text { batches }\end{array}$} & \multirow{2}{*}{$\begin{array}{c}\text { Initial } \\
\text { Quantity } \\
\text { Of } \\
\text { Karavella } \\
\text { ka Fruit } \\
\text { (gm) }\end{array}$} & \multicolumn{3}{|c|}{$\begin{array}{l}\text { Weight changes after removing } \\
\text { seeds }\end{array}$} & \multirow{2}{*}{$\begin{array}{c}\text { Weight } \\
\text { of paste } \\
\text { (gm) }\end{array}$} & \multirow{2}{*}{$\begin{array}{c}\text { Weight } \\
\text { after } \\
\text { Drying }\end{array}$} & \multirow{2}{*}{$\begin{array}{c}\text { Powder } \\
\text { weight } \\
\text { after } \\
\text { sieving } \\
\text { (gm) }\end{array}$} & \multirow{2}{*}{$\begin{array}{l}\text { \% weight } \\
\text { loss } \\
\text { compare } \\
\text { d to } \\
\text { initial } \\
\text { quantity }\end{array}$} \\
\hline & & & $\begin{array}{l}\text { Obtained } \\
\text { quantity } \\
\text { (gm) }\end{array}$ & $\begin{array}{l}\text { Loss } \\
\text { (gm) }\end{array}$ & $\begin{array}{l}\% \text { weight } \\
\text { loss }\end{array}$ & & & & \\
\hline \multirow[t]{3}{*}{$\mathrm{KC}$} & 1 & 1000 & 854 & 146 & 14.6 & 845 & 81.1 & 76.2 & 92.38 \\
\hline & 2 & 1000 & 850 & 150 & 15 & 840 & 80.5 & 74.1 & 92.59 \\
\hline & 3 & 1000 & 840 & 160 & 16 & 829 & 79.3 & 72.5 & 92.75 \\
\hline Average & 1000 & 848 & 152 & 15.20 & 838 & 80.30 & 74.26 & 92.57 & \\
\hline \multirow[t]{3}{*}{$\mathrm{BKC}$} & 4 & 1000 & 850 & 150 & 15 & 841 & 80.8 & 74.9 & 92.51 \\
\hline & 5 & 1000 & 852 & 148 & 14.8 & 842 & 81.4 & 75.3 & 92.47 \\
\hline & 6 & 1000 & 846 & 154 & 15.4 & 837 & 82.2 & 73.4 & 92.66 \\
\hline Average & 1000 & 849.33 & 150.66 & 15.06 & 840 & 81.46 & $\mathbf{7 4 . 5 3}$ & 92.54 & \\
\hline
\end{tabular}

Table 3: Extraction of juice of M. charantia

\begin{tabular}{|c|c|c|c|}
\hline Sr. & $\begin{array}{c}\text { Weight of Karavellaka fruits } \\
(\mathbf{g m})\end{array}$ & Weight of paste (gm) & $\begin{array}{c}\text { Obtained quantity of juice } \\
(\mathbf{m l})\end{array}$ \\
\hline 1 & 1000 & 847 & 345 \\
\hline 2 & 1000 & 844 & 344 \\
\hline 3 & 1000 & 832 & 320 \\
\hline Average & $\mathbf{1 0 0 0}$ & $\mathbf{8 4 1}$ & $\mathbf{3 3 6 . 3 3}$ \\
\hline
\end{tabular}

Table 4: Observations of preparation of BKC

\begin{tabular}{|c|c|c|c|c|c|c|c|c|}
\hline \multirow{2}{*}{ Batch } & \multirow{2}{*}{$\begin{array}{l}\text { Quantity } \\
\text { of powder } \\
\text { (gm) }\end{array}$} & \multicolumn{3}{|c|}{$\begin{array}{c}\text { Number \& Quantity of juice for } \\
\text { Bhavana }(\mathrm{ml})\end{array}$} & \multirow{2}{*}{$\begin{array}{l}\text { Average } \\
\text { quantity of } \\
\text { juice for } \\
\text { Bhavana }\end{array}$} & \multirow{2}{*}{$\begin{array}{c}\text { Average } \\
\text { duration } \\
\text { of } \\
\text { Bhavana } \\
\text { (for } 3 \\
\text { days) }\end{array}$} & \multirow{2}{*}{$\begin{array}{l}\text { Weight of } \\
\text { obtained } \\
\text { BKC (gm) }\end{array}$} & \multirow{2}{*}{$\begin{array}{l}\% \text { weight } \\
\text { gain }\end{array}$} \\
\hline & & 1st & 2nd & 3rd & & & & \\
\hline BKC-1 & 74.9 & 120 & 115 & 105 & 113.33 & $\begin{array}{c}2.40 \text { hours/ } \\
\text { day }\end{array}$ & 82 & 9.48 \\
\hline BKC-2 & 75.3 & 120 & 110 & 100 & 110.00 & $\begin{array}{l}2.40 \text { hours/ } \\
\text { day }\end{array}$ & 86 & 14.21 \\
\hline BKC-3 & 73.4 & 120 & 100 & 100 & 106.67 & $\begin{array}{c}2.40 \text { hours/ } \\
\text { day }\end{array}$ & 80 & 8.99 \\
\hline Average & 74.53 & 120 & 108.33 & 101.66 & 110.00 & $\begin{array}{c}3.40 \text { hours/ } \\
\text { day }\end{array}$ & 82.66 & 10.89 \\
\hline
\end{tabular}


Table 5: Observations of organoleptic characters of $\mathrm{KC}$ and $\mathrm{BKC}$

\begin{tabular}{|c|c|c|c|}
\hline Sr. & Test & KC & BKC \\
\hline 1 & Colour & Greenish brown & Greenish brown \\
\hline 2 & Odour & Non specific & Non specific \\
\hline 3 & Taste & Bitter & Bitter \\
\hline 4 & Touch & Smooth powder & Smooth powder \\
\hline
\end{tabular}

Table 6: Observations of analysis of $\mathrm{KC}$ and $\mathrm{BKC}$

\begin{tabular}{|c|c|c|c|c|c|c|c|c|c|c|}
\hline \multirow{2}{*}{ Sr. } & \multirow{2}{*}{ Test } & \multirow{2}{*}{ API standard } & \multicolumn{4}{|c|}{$\mathrm{KC}$ (values in \% w/w) } & \multicolumn{4}{|c|}{ BKC (values in \% w/w) } \\
\hline & & & 1 & 2 & 3 & Average & 1 & 2 & 3 & Average \\
\hline 1 & Total ash & Not more than 8.5 & 6.7 & 6.4 & 6.5 & 6.53 & 7.4 & 7.6 & 7.2 & 7.40 \\
\hline 2 & Acid insoluble ash & Not more than 0.6 & 0.24 & 0.22 & 0.30 & 0.25 & 0.31 & 0.33 & 0.30 & 0.31 \\
\hline 3 & Water soluble ash & Not more than 4 & 3.54 & 3.48 & 3.51 & 3.51 & 3.7 & 3.6 & 3.7 & 3.67 \\
\hline 4 & $\begin{array}{l}\text { Alcohol-soluble } \\
\text { extractive }\end{array}$ & Not less than 6 & 18 & 20 & 19 & 19.00 & 21 & 24 & 23 & 22.67 \\
\hline 5 & $\begin{array}{l}\text { Water-soluble } \\
\text { extractive }\end{array}$ & Not less than 28 & 36.8 & 37.2 & 36.7 & 36.90 & 37.6 & 37.9 & 38.2 & 37.90 \\
\hline 6 & Foreign matter & Nil & Nil & Nil & Nil & Nil & Nil & Nil & Nil & Nil \\
\hline 7 & Moisture content & - & 3.20 & 3.18 & 3.20 & & 3.21 & 3.21 & 3.20 & \\
\hline 8 & $\begin{array}{c}\text { Microbial } \\
\text { contamination }\end{array}$ & Nil & Nil & Nil & Nil & Nil & Nil & Nil & Nil & Nil \\
\hline
\end{tabular}

Table 7: Analysis of nutritional value of $\mathrm{KC}$ and $\mathrm{BKC}$

\begin{tabular}{|c|c|c|c|c|c|}
\hline Sr. & Parameter & \multicolumn{2}{|c|}{$\mathrm{KC}(\%)$} & \multicolumn{2}{|c|}{ BKC $(\%)$} \\
\hline 1 & Protein & \multicolumn{2}{|c|}{1.54} & \multicolumn{2}{|c|}{5.98} \\
\hline 2 & Total Fat & \multicolumn{2}{|c|}{0.0} & \multicolumn{2}{|c|}{0.0} \\
\hline 3 & Carbohydrate & \multicolumn{2}{|c|}{25.43} & \multicolumn{2}{|c|}{73.10} \\
\hline \multirow[t]{7}{*}{4} & Total Minerals & \multicolumn{2}{|c|}{10.26} & \multicolumn{2}{|c|}{13.30} \\
\hline & & Calcium & 0.79 & Calcium & 1.02 \\
\hline & & Copper & 1.58 & Copper & 2.05 \\
\hline & & Iron & 1.97 & Iron & 2.56 \\
\hline & & Magnesium & 1.58 & Magnesium & 2.05 \\
\hline & & Manganese & 1.58 & Manganese & 2.05 \\
\hline & & Zinc & 2.76 & Zinc & 3.58 \\
\hline 5 & Crude fibers & 4.35 & & 5.71 & \\
\hline 6 & Total energy & $260.64 \mathrm{Kcal} / 100 \mathrm{gm}$ & & $316.32 \mathrm{Kcal} / 100 \mathrm{gm}$ & \\
\hline
\end{tabular}

\section{Discussion:}

The classical texts of Ayurveda as well as the development in Ayurveda pharmaceutics clearly represents that the ancient seers of Ayurveda has discovered and successfully practiced few pharmaceutical techniques which has significant role in changing pharmacokinetic properties of medicinal substances. Bhavana is one among such pharmaceutical procedures in which juice, decoction or liquid prepared from medicinal herbs is used to triturate one or more herbal or herbo-mineral combinations. Studies indicates that process of Bhavana results in impregnation of active molecules from the liquid utilized for Bhavana to the substance which is triturated.(11,12,13) In another words, Bhavana process can be used to enhance medicinal properties of a drug by triturating it with the liquid extracted from another drug which has similar potential. Here it can be claimed that this synergistic way of enhancing potential can be used in definite way by triturating a drug with liquid extracted from the same drug. The changes occurred after such procedure can be well accessed on analytical ground. Analytical studies has its own role in pre-clinical evaluation of possible potential in a medicinal product and thus analytical study serve as a creator of solid base for further researches on clinical ground. Considering these facts, 
present study was done on comparative analytical evaluation of $\mathrm{KC}$ and $\mathrm{BKC}$.

Fruits like $M$. Charantia have high proportion of liquid in fruit cells which result is significant weight loss after drying. In pilot study, attempt was made to make powder of $M$. Charantia fruit by making tiny pieces and then allowing them for shade drying followed by grinding in mixer. However it was noted that the tiny pieces of $M$. Charantia become much hard which made grinding difficult. Therefore instead of making small pieces, pulp of wet fruit was made in to paste in grinder and then the pulp was dried on hot air oven. This procedure is easy compared to making pieces. Still weight loss detected is about $92 \%$ which may indicates that only $8 \%$ portion of $M$. Charantia fruit includes fibers, proteins, carbohydrates, vitamins and minerals. Dried powder of $M$. Charantia was stored in airtight container to avoid microbial contaminations as well as to interaction with atmospheric changes. Powder prepared for BKC was subjected for Bhavana in wet grinder machine. Utilization of grinder helps in applying uniform pressure and friction which plays role in impregnation of chemical constitutes from liquid to the drug. Average $10.89 \%$ weight gain is detected after Bhavana in three batches of BKC. This observation itself represents addition of components of liquid in the dried powder. However as the juice contain cells and fibers of $M$. Charantia hence analysis was a must step to decide whether there is only increase in mass or actual increase in chemical constitutes too.

Physico-chemical analysis showed that all parameters are in range prescribed in Ayurvedic pharmacopoeia of India. Total ash of drug represents presence of inorganic or mineral content.(14) Observed Total ash in $\mathrm{BKC}$ is higher than $\mathrm{KC}$ which is also confirmed by nutritional analysis in which total mineral content in $\mathrm{BKC}$ is 13.30 and in $\mathrm{KC}$ it is 10.26 percent. This may also be reason behind higher value of acid insoluble ash in $\mathrm{BKC}$ compared to $\mathrm{KC}$. Few components of herbal drug are soluble in water while few are soluble in alcohol. The extent solubility describes which media is suitable solvent for extraction drug constitutes.(15) Alcohol and water-soluble extractives of both sample indicates better solubility in alcohol. However which soluble portion contain which constitutes is not clear and thus claim can not be made regarding which extractive can be used for therapeutic purpose. In both the test, KBC has higher solubility than $\mathrm{KC}$ which may be due to higher concentration of phytoconstitutes compared to $\mathrm{KC}$. Both samples were devoid of any microbial contamination or presence of any foreign matter which indicates proper care taken during preparation of $\mathrm{KC}$ and $\mathrm{BKC}$.

In nutritional analysis, presence of fat is not detected in both samples. Research indicates that total fat in M. Charantia fruit range from 2.9 to $6.4 \%$.(16) The reason behind absence of fat in both sample is unknown, however it can be interpreted that it may be due to geographical differences in the selected sample. The result may need to be revalidated by further repetition of similar research. Carbohydrates are the source of energy which even helps in maintaining energy while fasting.(17)

The proportion of carbohydrate in $\mathrm{KBC}$ is nearly three times higher than $\mathrm{KC}$. This finding clearly shows the higher nutritional value of $\mathrm{KBC}$ which is actually caused as effect of Bhavana. Similar observation is also found in total energy of the test drugs. Elements such as Calcium, Copper, Iron, Magnesium, Manganese and Zinc are proven to have major role in human physiology. Calcium helps in building bones and teeth; it activates various enzymes throughout body; also helps in regulating blood pressure; work on nerves for sending messages, and also helps in clotting of blood. Copper assists as metabolic fuel, plays role in making RBC (red blood cells), act as regulator for neurotransmitters, and for mopping up the free radicals. Iron is well known to help in making hemoglobin as well as myoglobin. Iron is also essential for activation of certain enzymes, collagen, making amino acids, hormones and neurotransmitters. Like calcium, Magnesium also participates in building bones and teeth. It also helps in regulating blood pressure, blood sugar, contraction of muscles, production of various enzymes, and clotting of blood. Manganese helps to metabolize amino acids, carbohydrates and cholesterol. Zinc act on blood clotting, production of proteins and DNA, as immunomodulator, and also helps in healing of wound. (18) More proportion of all these elements in BKC is an evidence of impregnation of constitutes of $M$. Charantia juice into its powder which further highlights significance of Bhavana in increasing therapeutic potential of the drug as well as its synergistic action.

\section{Conclusions}

Bhavana of $M$. Charantia juice plays vital role in increasing concentration of various constitutes present in its powder form. Therapeutic potential of a drug can be significantly increased by Bhavana to that drug by its own juice. Present study also proves the Ayurveda claim of changes in drug attributes by applying Bhavana. The analytical profile of BKC indicates further need of research on clinical ground to know its dose and intensity of action as an anti-diabetic agent as well as in other systemic disorders. 


\section{Figures:}
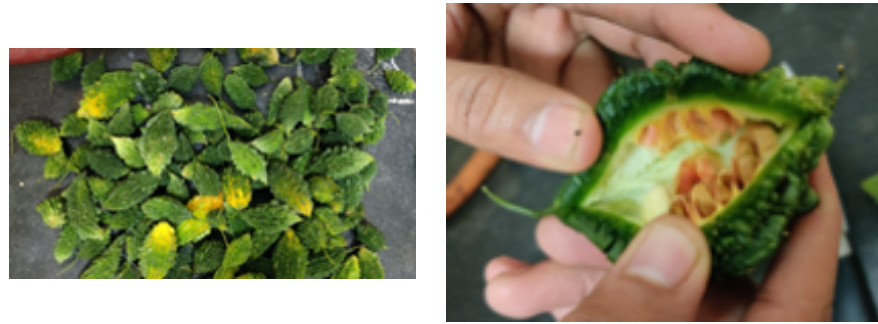

Fig. 1: Procured $M$. Charantia fruits

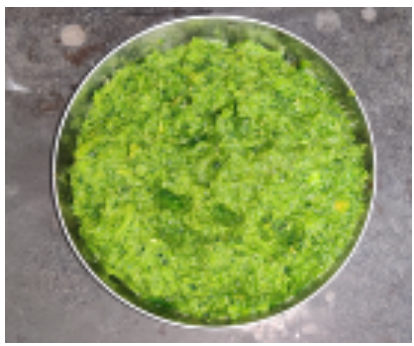

Fig.5: M. Charantia Pulp for drying to prepare $\mathrm{KC}$

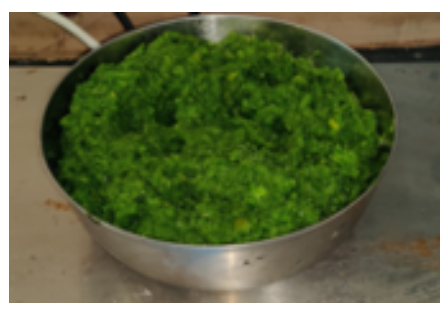

Fig.2: Removing of seeds

Fig.6: M. Charantia Pulp for Bhavana to prepare BKC

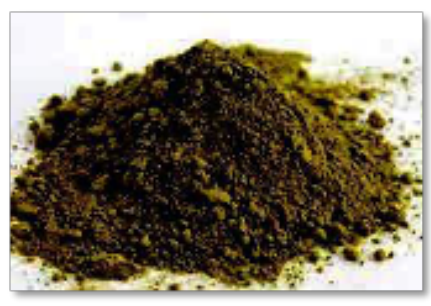

Fig.9: Prepared KC

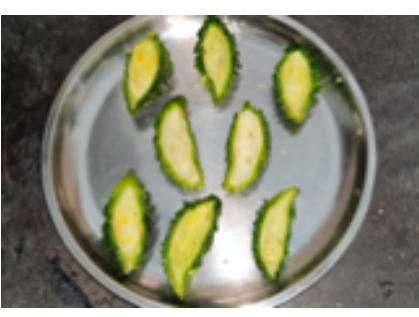

Fig.3: M. Charantia after removing seeds

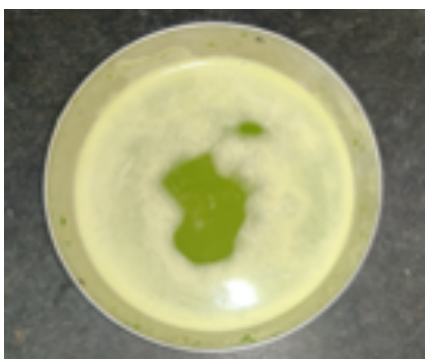

Fig.7: Extracted juice of $M$. Charantia

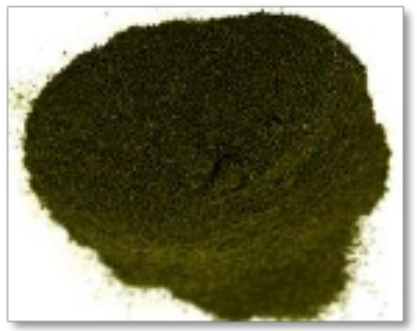

Fig.10: Prepared BKC

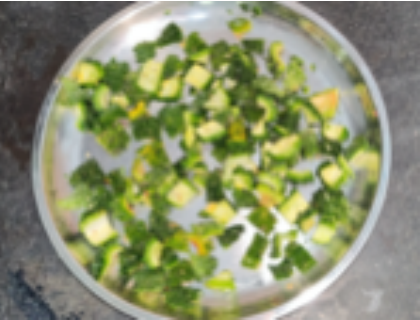

Fig. 4: Small pieces of $M$. Charantia

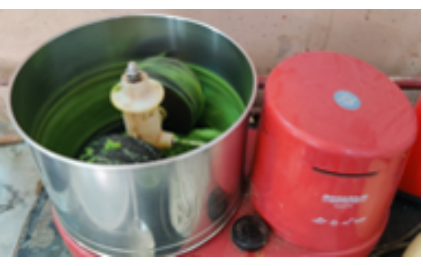

Fig. 8: Bhavana procedure

7. Morris BJ. The chemical analysis of food and food product. 3 ${ }^{\text {rd }}$ Ed, 1958, Van Nostrand Reinhold Company Publication, New York, p.600-601

8. The Declaration of Allulose and Calories from Allulose on Nutrition and Supplement Facts Labels: Guidance for Industry, FDA, April 2019, Available at https://www.fda.gov/media/123342/download, last accessed on 05/03/2020 at $11.51 \mathrm{AM}$.

3. Wild S, Roglic G, Green A, Sicree R, King H. Global prevalence of diabetes-estimates for the year 2000 and projections for 2030. Diabetes Care. 2004;27(3):1047-53.

4. https://www.dartmouth-hitchcock.org/endo/prediabetes.html, last accessed on 01-01-2019 at 9.57 $\mathrm{AM}$

5. KhanV, Najmi AK, Akhtar M, Aqil M, Mujeeb M, Pillai KK. A pharmacological appraisal of medicinal plants with antidiabetic potential. J Pharm Bioallied Sci. 2012 Jan-Mar; 4(1): 27-42.

6. Standard operating procedures, plant protein determination, available at https://clu-in.org/ download/ert/2033-R01.pdf

9. AOAC, Official methods of analysis of the Association of Official Analytical Chemists. 14th Ed. 14, DC. ed. 1984, Washington: Washington, DC.

10. AOAC, Official methods of analysis of the Association of Official Analytical Chemists. 14th Ed. 14, DC. ed. 1984, Washington: Washington, DC.

11. Rajput DS, Suryavanshi P, Suryavanshi S, Basic principles of Rasashastra - The Indian pharmaceutics of herbo-mineral preparations. International J Applied Ayurved Res, 2016;2(9):1262-68 
12. Usha P. Bhavana Samskara Improves The Pharmacognostic Values Of Antidiabetic Ayurvedic Formulation, Nishamalaki Curna. International J Ayurvedic and Herbal Med, 2016;6(1):1275-81

13. Rathi B, Rathi R, Rajput DS. Pharmaceutical Standardization of Avalgujadi Lepaguti, J Ind Sys Med, 2016:6(2):72-76

14. Rajput DS, Patgiri BJ, Galib R, Prajapati PK. Comparative analytical evaluation of Naga Bhasma prepared by two different methods. J. Ind. Sys.Med. 2018;6(3):100-114

15. Ajazuddin, Saraf S. Evaluation of physicochemical and phytochemical properties of Safoof-E-Sana, a Unani polyherbal formulation, Pharmacognosy Res. 2010:2(5):318-22.
16. Sorifa AM. Nutritional compositions, health promoting phytochemicals and value added products of bitter gourd: a review, International Food Research Journal 2018:25(5) 1763-1772

17. Kokkinidou S, Peterson D, Bloch T, Bronston A. The important role of carbohydrates in the flavor, function, and formulation of oral nutritional supplements, Nutrients 2018:10;742:1-10

18. Harward health publishing, Harvard medical school, Precious metals and other important minerals for health. Available at https:// www.health.harvard .edu/staying-healthy/preciousmetals-and-other-important-minerals-for-health, last accessed on 18-02-2020 at 02.10 PM. 